\title{
Originals
}

\section{The NSY mouse: a new animal model of spontaneous NIDDM with moderate obesity}

\author{
H. Ueda ${ }^{1}$, H. Ikegami ${ }^{1}$, E. Yamato ${ }^{1}$, J. Fu ${ }^{1}$, M.Fukuda ${ }^{1}$, G. Shen ${ }^{1}$, Y. Kawaguchii ${ }^{1}$, K. Takekawa ${ }^{1}$, Y.Fujioka ${ }^{1}$, \\ T. Fujisawa ${ }^{1}$, Y. Nakagawa ${ }^{1}$, Y.Hamada ${ }^{1}$, M. Shibata ${ }^{2}$, T. Ogihara ${ }^{1}$
}

${ }^{1}$ Department of Geriatric Medicine, Osaka University Medical School, Suita, Osaka, Japan

${ }^{2}$ Department of Health, Aichi-gakuin University, College of General Education, Aichi, Japan

\begin{abstract}
Summary The NSY (Nagoya-Shibata-Yasuda) mouse was established as an inbred strain of mouse with spontaneous development of diabetes mellitus, by selective breeding for glucose intolerance from outbred Jcl:ICR mice. NSY mice spontaneously develop diabetes mellitus in an age-dependent manner. The cumulative incidence of diabetes is $98 \%$ in males and $31 \%$ in females at 48 weeks of age. Neither severe obesity nor extreme hyperinsulinaemia is observed at any age in these mice. Glucose-stimulated insulin secretion was markedly impaired in NSY mice after 24 weeks of age. In contrast, fasting plasma insulin level was higher in male NSY mice than that in male $\mathrm{C} 3 \mathrm{H} / \mathrm{He}$ mice $(545 \pm 73$ vs $350 \pm$ $40 \mathrm{pmol} / 1, p<0.05$, at 36 weeks of age). Pancreatic insulin content was higher in male NSY mice than that in male $\mathrm{C} 3 \mathrm{H} / \mathrm{He}$ mice ( $76 \pm 8$ vs $52 \pm 5 \mathrm{ng} / \mathrm{mg}$ wet weight, $p<0.05$, at 36 weeks of age). Morphologically, no abnormal findings, such as hypertrophy or in-
\end{abstract}

flammatory changes in the pancreatic islets, were observed in NSY mice at any age. These data suggest that functional changes of insulin secretion in response to glucose from pancreatic beta cells may contribute to the development of non-insulin-dependent diabetes mellitus (NIDDM) in the NSY mouse. Although insulin sensitivity was not measured, fasting hyperinsulinaemia in NSY mice suggests that insulin resistance may also contribute to the pathogenesis of NIDDM. Since these findings are similar to the pathophysiologic features of human NIDDM patients, the NSY mouse is considered to be useful for investigating the pathogenesis and genetic predisposition to NIDDM. [Diabetologia (1995) 38: 503-508]

Key words NSY mouse, non-insulin-dependent diabetes mellitus, animal model, insulin secretion, isolated islets.
Non-insulin-dependent diabetes mellitus (NIDDM) is a heterogeneous disorder, caused by an interaction of genetic and environmental factors [1-3]. This heterogeneity in human NIDDM makes it difficult to clarify the genetics or pathogenesis of the disease. Animal models are invaluable for the analysis of heterogeneous disorders such as diabetes. This is evi-

Received: 22 June 1994 and in revised form: 11 October 1994

Corresponding author: Dr. H. Ikegami, Department of Geriatric Medicine, Osaka University Medical School, 2-2 Yamadaoka, Suita, Osaka 565, Japan

Abbreviations: NIDDM, Non-insulin-dependent diabetes mellitus; IDDM, insulin-dependent diabetes mellitus; NSY mouse, Nagoya-Shibata-Yasuda mouse. denced by the recent progress in the understanding of the genetics and pathogenesis of insulin-dependent diabetes mellitus by use of excellent animal models, such as the nonobese diabetic (NOD) mouse and the Bio-Breeding (BB) rat [4]. Several animal models for NIDDM have been described. Although recent studies have revealed impaired insulin secretion in GK rats [5-7], most of the animal models for NIDDM are characterized by obesity, hyperinsulinaemia and islet hypertrophy [8].

The NSY (Nagoya-Shibata-Yasuda) mouse is a spontaneous model of NIDDM with moderate obesity that was established by selective breeding for glucose intolerance from a non-diabetic Jcl:ICR mouse colony [9]. Previous studies suggested that NSY mice develop renal lesions similar to diabetic nephro- 
pathy [10]. However, the phenotypic characteristics and pathogenesis of diabetes in this strain are largely unknown. In this study, we investigated the longitudinal characteristics of glucose tolerance and insulin secretory capacity of the NSY mouse.

\section{Materials and methods}

Breeding of NSY mice. Three pairs of NSY mice (F36) were originally obtained from the Branch Hospital of Nagoya University School of Medicine, and the colony of NSY mice was maintained in the animal facilities of Osaka University Medical School by brother-sister mating with selective breeding for glucose intolerance. NSY mice from F37 to F42 generations were used in this study. $\mathrm{C} 3 \mathrm{H} / \mathrm{He}$ mice (Charles River Japan, Kanagawa, Japan) were used as the non-diabetic control strain. Jcl:ICR mice, from which NSY mice were derived, were not used as the control strain because they are outbred and therefore glucose tolerance in Jcl:ICR mice may have large variations. As a preliminary study, we studied glucose tolerance in several inbred strains of mice, such as BALB/c, $\mathrm{DBA} / 2, \mathrm{C} 3 \mathrm{H} / \mathrm{He}$, and $\mathrm{C} 57 \mathrm{BL} / 6$ mice at 24 weeks of age. All these strains showed similar glucose tolerance except for C57BL/6 mice which were the most glucose intolerant (data not shown) as previously reported by others $[8,11]$. Since the $\mathrm{C} 3 \mathrm{H} / \mathrm{He}$ strain is the second most common strain used as experimental mice after the C57BL/6 strain [12], we chose C3H/ He mice as the control strain. All mice were given a laboratory diet, MF (Oriental Yeast, Tokyo, Japan), containing $24.6 \%$ protein, $5.6 \%$ fat, $3.1 \%$ fiber, $6.3 \%$ ash and $52.8 \%$ complex carbohydrate and tap water ad libitum in an air-conditioned room $\left(22-25^{\circ} \mathrm{C}\right)$ with a 12 -h light/dark cycle.

Glucose tolerance test. Intraperitoneal glucose tolerance test (i. p.GTT) was performed by injecting glucose $(2 \mathrm{~g} / \mathrm{kg}$ in $20 \%$ solution) intraperitoneally in overnight-fasted mice at $4,8,12$, 24,36 and 48 weeks of age. Blood samples were obtained from the tail vein. Blood glucose concentration was measured directly by a glucose oxidase method using Glutest $\mathrm{E}$ (Kyoto Daiichi Kagaku, Kyoto, Japan) [13]. Diabetes was defined as a blood glucose concentration at 120 min during i.p.GTT higher than $11.1 \mathrm{mmol} / \mathrm{l}$. For measurement of insulin $300 \mu \mathrm{l}$ whole blood was collected from the tail vein without anaesthesia at $0 \mathrm{~min}$ and $30 \mathrm{~min}$ during i.p.GTT and immediately placed on ice. Plasma was prepared by centrifugation. Plasma insulin was measured by RIA (ShionoRIA insulin, Shionogi, Osaka, Japan) with rat insulin (Novo, Copenhagen, Denmark) as a standard [14].

Measurements of phenotypic characteristics and pancreatic insulin content. After anaesthetization (pentobarbital; $50 \mathrm{mg} / \mathrm{kg}$, i.p.), body weight and anal-nasal length were measured. Body mass index was calculated as body weight (g) divided by the square of the anal-nasal length $(\mathrm{cm})$. The pancreas and epididymal fat pads were dissected and weighed. Insulin was extracted from the pancreas by the acid ethanol method [15] and measured by radioimmunoassay.

In vitro assessment of insulin secretory capacity. In vitro insulin secretory capacity in isolated islets was measured by the batch incubation method. Pancreatic islets were isolated from male NSY and $\mathrm{C} 3 \mathrm{H} / \mathrm{He}$ mice at 12 weeks of age by collagenase digestion [16]. The isolated islets were cultured overnight in RPMI1640 medium (Sigma, St. Louis, Mo., USA) containing $11.1 \mathrm{mmol} / 1$ glucose, $10 \%$ fetal calf serum and

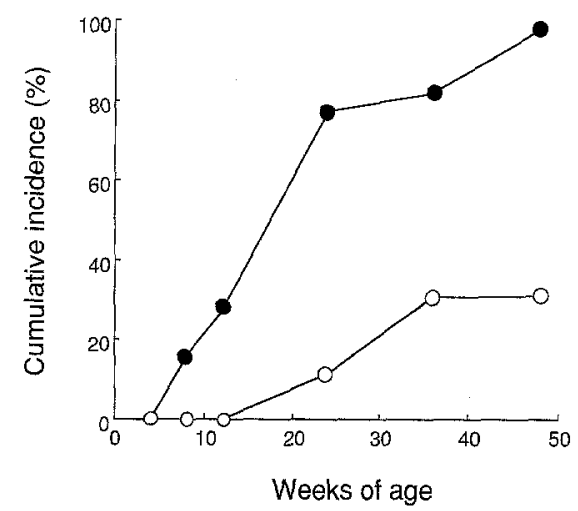

Fig. 1. Cumulative incidence of diabetes among male $(\bullet)$ and female (O) NSY mice at 4-48 weeks of age. Fourteen to 50 mice were examined at various ages

$1 \%$ glutamic acid. The isolated islets were pre-incubated for $60 \mathrm{~min}$ at $37^{\circ} \mathrm{C}$ in Hank's balanced salt solution (HBSS) medium with $5.5 \mathrm{mmol} / \mathrm{l}$ glucose and $0.1 \%$ bovine serum albumin. Each batch of 10 islets was incubated for $60 \mathrm{~min}$ at $37^{\circ} \mathrm{C}$ in $1.0 \mathrm{ml}$ HBSS medium with $0.1 \%$ bovine serum albumin and different glucose concentrations (5.5 or $16.7 \mathrm{mmol} / \mathrm{l}$ ) or L-arginine $(5.5 \mathrm{mmol} / \mathrm{l}$ glucose $+20 \mathrm{mmol} / \mathrm{l} \mathrm{L}$-arginine $)$. Following incubation, the islets were collected by centrifugation. The insulin concentration of the incubation media was measured by radioimmunoassay. DNA content in the islets was measured by a fluorometric procedure [17]. The insulin release from the islets was calculated and corrected by DNA content of the islets.

Histological examination. Histology of pancreatic islets was studied in male NSY and $\mathrm{C} 3 \mathrm{H} / \mathrm{He}$ mice at 8 and 48 weeks of age. The pancreas was dissected and then fixed in neutralized $10 \%$ formalin. Paraffin sections of the pancreas were stained with haematoxylin-eosin by the standard method. Islet mass of male NSY and $\mathrm{C} 3 \mathrm{H} / \mathrm{He}$ mice at 48 weeks of age was quantified by a microcomputer imaging device (Imaging Research Inc., Ontario, Canada).

\section{Statistical analysis}

All results are expressed as mean \pm SEM. Statistical analysis was performed by Student's $t$ test.

\section{Results}

Diabetes in NSY mice. Figure 1 shows the cumulative incidence of diabetes in NSY mice. At 4 weeks of age, the incidence of diabetes in NSY mice was $0 \%$ in both males (0/14) and females (0/17). NSY mice spontaneously developed diabetes in an age-dependent manner. The cumulative incidence of diabetes reached $98 \%$ (49 of 50) in male NSY mice and $31 \%$ ( 9 of 29 ) in female NSY mice at 48 weeks of age.

Growth curve of NSY mice. Body weight of male NSY mice was moderately greater than that of male 

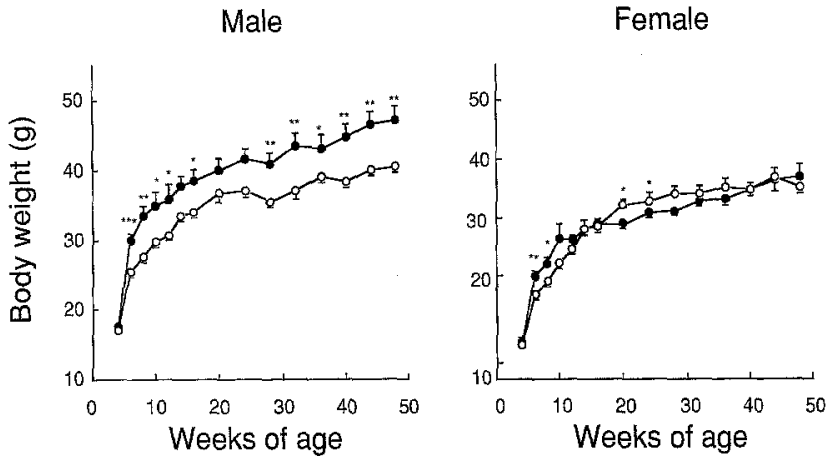

Fig. 2. Body weight changes in $\mathrm{C} 3 \mathrm{H} / \mathrm{He}(\mathrm{O})$ and NSY (•) mice from $4-48$ weeks of age. $n=4-5$ in each group. Values are mean $\pm \mathrm{SEM}$.

$* p<0.05 ;{ }^{* *} p<0.01 ; * * * p<0.001$ vs C3H/He mice

Table 1. Phenotypic characterization of male $\mathrm{C} 3 \mathrm{H} / \mathrm{He}$ and NSY mice at 36 weeks of age

\begin{tabular}{|c|c|c|c|}
\hline & $\begin{array}{l}\mathrm{C} 3 \mathrm{H} / \mathrm{He} \text { mice } \\
n=5\end{array}$ & $\begin{array}{l}\text { NSY mice } \\
n=5\end{array}$ & $p$ \\
\hline Body weight (g) & $37.3 \pm 1.2$ & $51.2 \pm 1.4$ & $<0.001$ \\
\hline Length $(\mathrm{cm})$ & $10.7 \pm 0.06$ & $11.2 \pm 0.02$ & $<0.001$ \\
\hline $\mathrm{BMI}\left(\mathrm{g} \cdot \mathrm{cm}^{-2}\right)$ & $0.32 \pm 0.06$ & $0.41 \pm 0.01$ & $<0.001$ \\
\hline $\begin{array}{l}\text { Weight of epididymal } \\
\text { fat pads (g) }\end{array}$ & $0.96 \pm 0.10$ & $1.73 \pm 0.13$ & $<0.01$ \\
\hline $\begin{array}{l}\text { Fasting blood glucose } \\
(\mathrm{mmol} / \mathrm{l})\end{array}$ & $5.4 \pm 0.3$ & $5.0 \pm 0.2$ & N.S. \\
\hline $\begin{array}{l}\text { Non-fasting blood } \\
\text { glucose }(\mathrm{mmol} / 1)\end{array}$ & $6.3 \pm 1.0$ & $9.0 \pm 1.8$ & $<0.001$ \\
\hline $\begin{array}{l}\text { Fasting plasma insulin } \\
(\mathrm{pmol} / \mathrm{l})\end{array}$ & $305 \pm 40$ & $545 \pm 73$ & $<0.05$ \\
\hline $\begin{array}{l}\text { Non-fasting plasma } \\
\text { insulin }(\mathrm{pmol} / \mathrm{l})\end{array}$ & $641 \pm 180$ & $1270 \pm 289$ & N.S. \\
\hline Pancreatic weight (mg) & $234 \pm 11$ & $281 \pm 4$ & $<0.01$ \\
\hline $\begin{array}{l}\text { Pancreatic insulin content } \\
\left(\mathrm{ng} \cdot \text { mg wet weight }^{-1}\right)\end{array}$ & $52 \pm 5$ & $76 \pm 8$ & $<0.05$ \\
\hline
\end{tabular}

Values are mean \pm SEM. N.S., Not significant
$\mathrm{C} 3 \mathrm{H} / \mathrm{He}$ mice after 6 weeks of age. Body weight of female NSY mice was similar to that of female $\mathrm{C} 3 \mathrm{H} / \mathrm{He}$ mice (Fig. 2).

Phenotypic characteristics in male diabetic NSY mice at 36 weeks of age. Phenotypic characteristics were examined in diabetic male NSY mice and male $\mathrm{C} 3 \mathrm{H} /$ $\mathrm{He}$ mice (Table 1). The body weight, anal-nasal length and body mass index of NSY mice were significantly greater than those of $\mathrm{C} 3 \mathrm{H} / \mathrm{He}$ mice $(p<0.001)$. Weight of epididymal fat pads was significantly greater in NSY mice than that in $\mathrm{C} 3 \mathrm{H} / \mathrm{He}$ mice $(p<0.01)$. Fasting blood glucose was comparable between the two strains. Non-fasting blood glucose was significantly higher in NSY mice than that in $\mathrm{C} 3 \mathrm{H} / \mathrm{He}$ mice $(p<0.001)$. Fasting plasma insulin of NSY mice was significantly higher than that of $\mathrm{C} 3 \mathrm{H} / \mathrm{He}$ mice $(p<0.05)$. Pancreatic insulin content of NSY mice was significantly higher than that of $\mathrm{C} 3 \mathrm{H} / \mathrm{He}$ mice at 36 weeks of age $(p<0.05)$. In contrast, no significant differences were observed in pancreatic insulin content at younger ages (NSY vs C3H/ $\mathrm{He}: 34 \pm 4$ vs $34 \pm 5 \mathrm{ng} / \mathrm{mg}$ wet weight at 8 weeks of age; $24 \pm 4$ vs $23 \pm 4 \mathrm{ng} / \mathrm{mg}$ wet weight at 12 weeks of age) ( $n=5$, respectively). Pancreatic insulin content in NSY mice at 36 weeks of age was significantly higher than that at 8 and 12 weeks of age $(p<0.05$ for both).

In vivo insulin response to glucose and insulin content of pancreas. Longitudinal changes in insulin response to glucose were examined (Fig. 3). Insulin response to glucose was comparable in the two strains at 8 weeks of age. However, after 12 weeks of age, insulin response to glucose was impaired in NSY mice. In contrast, fasting plasma insulin concentration of NSY mice was significantly elevated compared to that of $\mathrm{C} 3 \mathrm{H} / \mathrm{He}$ mice at 24 and 36 weeks of age $(p<0.05)$.
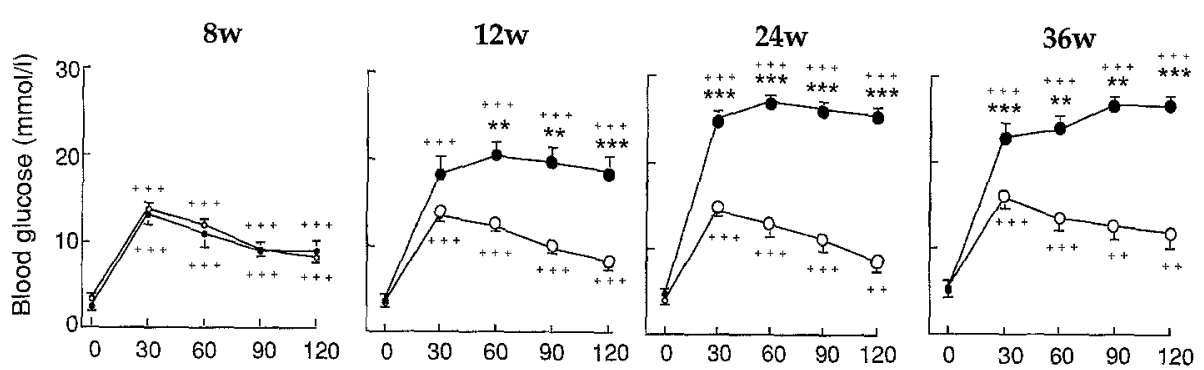

Fig. 3. Longitudinal analysis of glucose tolerance and insulin response to glucose during intraperitoneal glucose tolerance test ( $2 \mathrm{~g} / \mathrm{kg}$ body weight) in male, overnight-fasted $\mathrm{C} 3 \mathrm{H} / \mathrm{He}(\mathrm{O})$
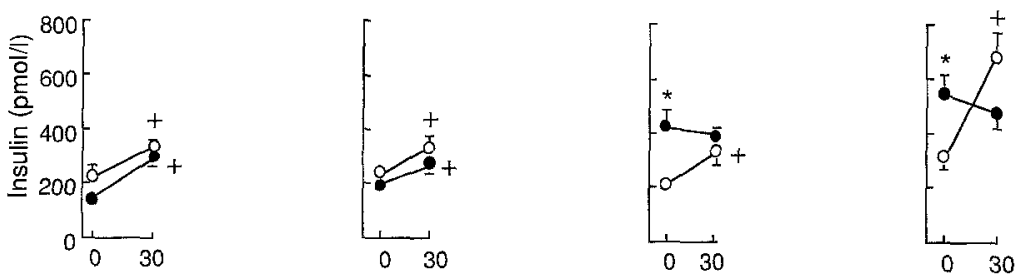
and NSY (-) mice from 8-36 weeks of age. $n=5-6$ in each group. Values are mean \pm SEM.

$* p<0.05$; ** $p<0.01$; *** $p<0.001$ vs male $\mathrm{C} 3 \mathrm{H} / \mathrm{He}$ mice. $+p<0.05 ;++p<0.01 ;+++p<0.001$ vs basal 
Table 2. Insulin release from isolated islets

\begin{tabular}{|c|c|c|c|}
\hline & \multicolumn{2}{|l|}{ Glucose } & \multirow{2}{*}{$\begin{array}{l}\text { Arginine } \\
20 \mathrm{mmol} / 1\end{array}$} \\
\hline & $5.5 \mathrm{mmol} / \mathrm{l}$ & $16.7 \mathrm{mmol} / 1$ & \\
\hline NSY & $28.1 \pm 7.5$ & $43.5 \pm 5.2$ & $50.9 \pm 7.0^{\mathrm{a}}$ \\
\hline $\mathrm{C} 3 \mathrm{H} / \mathrm{He}$ & $29.7 \pm 2.7$ & $54.2 \pm 9.0^{\mathrm{b}}$ & $45.2 \pm 5.3^{b}$ \\
\hline
\end{tabular}

Values (pg $\cdot \mathrm{ng}$ islet $\mathrm{DNA}^{-1} \cdot \mathrm{h}^{-1}$ ) are mean $\pm \mathrm{SEM}$ for seven or eight individual experiments.

Arginine was tested in the presence of $5.5 \mathrm{mmol} / 1$ glcuose.

${ }^{a} p<0.05$ vs NSY basal.

${ }^{\mathrm{b}} p<0.05$ vs $\mathrm{C} 3 \mathrm{H} / \mathrm{He}$ basal.

No significant difference was found between NSY and C3H/He mice

In vitro insulin secretory capacity. Insulin responses to glucose and a non-glucose stimulus were examined in vitro using isolated islets from male NSY and $\mathrm{C} 3 \mathrm{H} /$ $\mathrm{He}$ mice at 12 weeks of age (Table 2). In $\mathrm{C} 3 \mathrm{H} / \mathrm{He}$ mice, insulin response to $16.7 \mathrm{mmol} / 1$ glucose was significantly greater than that to $5.5 \mathrm{mmol} / \mathrm{l}$ glucose $(p<0.05)$, whereas no significant increase in insulin release induced by glucose was observed in NSY mice. In contrast, insulin release was significantly increased by $\mathrm{L}$-arginine in NSY as well as $\mathrm{C} 3 \mathrm{H} / \mathrm{He}$ mice $(p<0.05)$.

Histological examination of pancreas. Histological examination showed that neither severe hypertrophy and/or hyperplasia, nor inflammatory changes were observed in islets of NSY mice at 8 and 48 weeks of age. Since the islets of NSY mice at 48 weeks age were slightly larger than those of $\mathrm{C} 3 \mathrm{H} / \mathrm{He}$ mice (Fig.4), we studied the percentage of islet area by quantitative analysis. Islet area of NSY mice was slightly, but not significantly, larger than that of $\mathrm{C} 3 \mathrm{H} / \mathrm{He}$ mice $(1.2 \pm 0.3 \% ; n=4$, vs $0.9 \pm 0.2 \%$; $n=4$ ).

\section{Discussion}

NSY mice spontaneously develop diabetes in an agedependent manner. The late onset of diabetes in NSY mice closely resembles the features of human NIDDM. The cumulative incidence of diabetes was $98 \%$ in males and $31 \%$ in females at 48 weeks of age. A higher incidence of diabetes in males than that in females is also reported in other animal models of NIDDM [8].

Body weights of male NSY mice were moderately greater than those of male $\mathrm{C} 3 \mathrm{H} / \mathrm{He}$ mice after 6 weeks of age. In addition, epididymal fat pad weight in NSY mice was significantly greater than that in $\mathrm{C} 3 \mathrm{H} / \mathrm{He}$ mice. These characteristics are similar to those observed in human NIDDM in which visceral fat accumulation is a risk factor for glucose intolerance even in patients with mild obesity [18]. Moreover, fasting hyperinsulinaemia as observed in

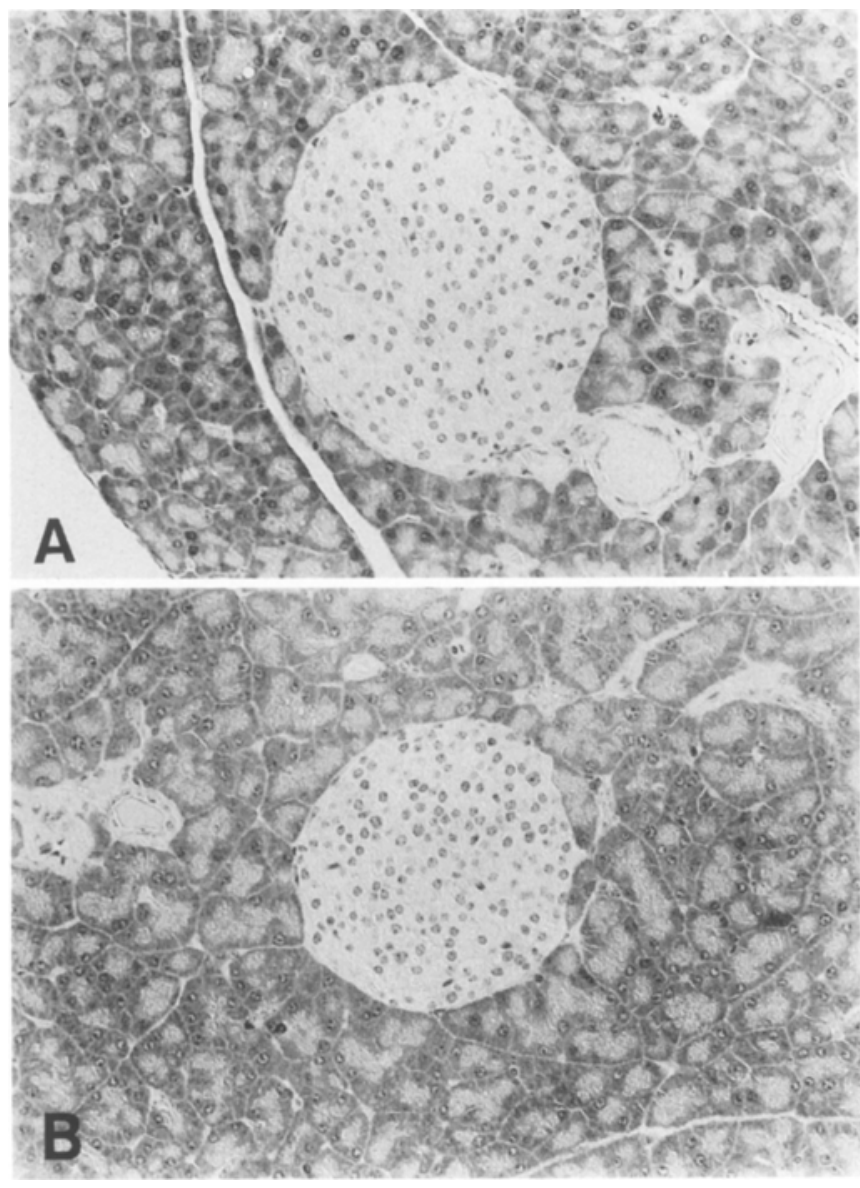

Fig. 4. Histologic appearance of pancreatic islets of male nondiabetic $\mathrm{C} 3 \mathrm{H} / \mathrm{He}$ mice (A) and male diabetic NSY mice (B) at 48 weeks of age. Haematoxylin and eosin stain. Magnification, $\times 200$

NSY mice is also reported in patients with NIDDM [19, 20].

Glucose-stimulated insulin secretion was markedly impaired in NSY mice after 24 weeks of age. In contrast, the pancreatic insulin content of NSY mice was maintained up to 36 weeks of age. In addition, insulin response to L-arginine was maintained in NSY mice. These observations suggest that the islets of NSY mice retain the ability to synthesize insulin and to release insulin in response to non-glucose stimulus, but insulin response to glucose is impaired. Further studies are underway to determine the molecular mechanisms of the impaired insulin response to glucose in NSY mice.

Fasting plasma insulin levels of NSY mice at 24 and 36 weeks of age were higher than those of younger mice, whereas no significant difference was observed in $\mathrm{C} 3 \mathrm{H} / \mathrm{He}$ mice. Impairment of insulin action with advancing age is responsible for the decline of glucose tolerance with age in humans [21]. Although insulin sensitivity was not measured in the present study, fasting hyperinsulinaemia in NSY mice of older age suggests that insulin resistance as 
well as impaired insulin secretion contributes to the deterioration of glucose tolerance. Morphologically, neither islet hypertrophy nor lymphocytic infiltration into or around islets was observed in NSY mice. These findings indicate that diabetes in NSY mice is not caused by autoimmunity.

In humans, NIDDM is usually of late onset and characterized by defects in both insulin secretion and action $[1,22]$. In these patients, glucose-stimulated insulin secretion is selectively impaired, but near normal response to L-arginine has been reported $[23,24]$. In fact, impaired insulin response to glucose has been suggested to be an important predisposing factor for the development of glucose intolerance in patients with NIDDM $[25,26]$.

Several animal models of NIDDM have been previously reported. Zucker fatty rats and C57BL/6 ob mice are characterized by severe obesity and severe hyperinsulinaemia, i.e., without impairment of insulin secretion. Although GK rats and C57/BL/Ks db mcie are characterized by loss of beta-cell function, diabetes is documented to be of early onset [8]. Only eSS rats were previously reported as an animal model of late-onset NIDDM without severe obesity similar to NSY mice [27].

It is of interest that NSY mice were derived from Jcl:ICR colony, from which NOD and NON mice were also derived. The NOD mouse is a well known animal model autoimmune IDDM [28]. NON mice are reported to show impaired glucose tolerance without inflammatory changes in pancreatic islets [29]. Thus, Jcl:ICR colony appears to contain the genetic pool for both IDDM and NIDDM, and this is one reason why we did not use this outbred strain as control mice.

Another interesting point in NSY mice is the gender difference in the incidence of diabetes, with a higher incidence in males than in females. Most, if not all, rodent models of NIDDM so far reported show a higher incidence of diabetes in males than in females, as in the case of NSY mice. A similar tendency is also reported in human NIDDM in some, but not all, ethnic groups [30,31]. Identification of the factors responsible for the sexual dimorphism in diabetes of NSY mice will provide information on the pathogenesis of NIDDM and effective methods for the prevention and intervention of NIDDM.

In NSY mice, diabetes is of late onset, and functional changes of insulin secretion in response to glucose appear to contribute to the development of NIDDM. Although we did not measure insulin sensitivity in this study, fasting hyperinsulinaemia in NSY mice suggests that insulin resistance may also contribute to the pathogenesis of diabetes. These characteristic features in the NSY mouse are similar to those in humans; thus, the NSY mouse appears to be a good animal model of human NIDDM. In addition, since abundant knowledge of the mouse genome has accumulated [32], the NSY mouse will be a useful model for studies on the genetics as well as the pathogenesis of NIDDM.

Acknowledgements. We thank Ms. Y. Ueno for her skillful technical support. This work was supported in part by a Grant for Diabetes Research from the Ministry of Health and Welfare, a Grant-in-Aid for Scientific Research from the Ministry of Education, Science and Culture of Japan, a Grant from the Japan Diabetes Foundation and a Grant from the Osaka Kidney Foundation (OKF94-0008).

\section{References}

1. Weir GC, Leahy JC (1994) Pathogenesis of non-insulin-dependent (type II) diabetes mellitus. In: Kahn CR, Weir GC (eds) Joslin's diabetes mellitus XIII. Lea \& Febiger, Pennsylvania, pp 240-264

2. Hamman RF (1992) Genetic and environmental determinants of non-insulin dependent diabetes mellitus (NIDDM). Diabetes Metab Rev 8: 287-338

3. Kanety H, Moshe S, Shafrir E, Lunenfeld B, Karasik A (1994) Hyperinsulinemia induces a reversible impairment in insulin receptor function leading to diabetes in the sand rat model of non-insulin-dependent diabetes mellitus. Proc Natl Acad Sci USA 91: 1853-1857

4. Shafrir E (1990) Diabetes in animals. In: Rifkin H, Porte D Jr (eds) Diabetes mellitus: theory and practice IV. Elsevier Science, New York, pp 299-340

5. Portha B, Serradas P, Bailbé D, Suzuki K, Goto Y, Giroix M (1991) $\beta$-cell insensitivity to glucose in the GK rat, a spontaneous nonobese model for type II diabetes. Diabetes 40 : 486-491

6. Östenson CG, Khan A, Abdel-Halim SM et al. (1993) Abnormal insulin secretion and glucose metabolism in pancreatic islets from the spontaneously diabetic GK rat. Diabetologia $36:$ : 3-8

7. Tsuura Y, Ishida H, Okamoto Yet al. (1993) Glucose sensitivity of ATP-sensitive $\mathrm{K}^{+}$channel is impaired in $\beta$-cells of the GK rat. Diabetes 42: 1446-1453

8. Shafrir E (1992) Animal models of non-insulin-dependent diabetes. Diabetes Metab Rev 8: 179-208

9. Shibata M, Yasuda B (1980) New experimental congenital diabetic mice (N.S. Y. mice). Tohoku J Exp Med 130: 139142

10. Shibata M (1983) Microangiopathy in diabetic N.S. Y. mice. In: Abe H, Hoshi M (eds) Diabetic macroangiopathy. University of Tokyo Press, Tokyo, pp 457-466

11. Surwit RS, Kuhn CM, Cochrane C, McCubbin JA, Feinglos MN (1988) Diet-induced type II diabetes in C57BL/6J mice. Diabetes 37: 1163-1167

12. Festing MFW (1979) Inbreeding and its consequences, and the history of the inbred strains. In: Festing MFW (eds) Inbred strains in biomedical research. The Macmillan Press Ltd., London, p 10

13. Lewis BD (1992) Laboratory evaluation of the Glucocard ${ }^{\mathrm{TM}}$ blood glucose test meter. Clin Chem 38: 2093-2095

14. Yamato E, Ikegami H, Tahara Y et al. (1993) Cellular mechanism of glyburide-induced insulin gene expression in isolated rat islets. Biochem Biophys Res Commun 197: 957-964

15. McEvoy RC (1984) Tissue culture of fetal rat pancreatic islets: quantitation of changes in the number of islet cells during culture. In: Larner J, Pohl SL (eds) Methods in diabetes research I part A. John Wiley, New York, p 236 
16. Yamato E, Noma Y, Tahara Y et al. (1990) Suppression of synthesis and release of glucagon by glucagon-like peptide-1 (7-36 amide) without affect on mRNA level in isolated rat islets. Biochem Biophys Res Commun 167: 431-437

17. Hinegardner RT (1971) An improved fluorometric assay for DNA. Anal Biochem 39: 197-201

18. Fujioka S, Matuzawa Y, Tokunaga K, Tarui S (1987) Contribution of intra-abdominal fat accumulation to the impairment of glucose and lipid metabolism in human obesity. Metabolism 36: 54-59

19. Ohmura T, Ueda K, Kiyohara Y et al. (1994) The association of the insulin resistance syndrome with impaired glucose tolerance and NIDDM in the Japanese general population: the Hisayama study. Diabetologia 37: 897-904

20. Saad MF, Knowler WC, Pettitt DJ, Nelson RG, Mott DM, Bennett PH (1988) The natural history of impaired glucose tolerance in the Pima Indians. N Engl J Med 8: 15001506

21. DeFronzo RA (1979) Glucose intolerance and aging. Diabetes 28: 1095-1101

22. Groop LC, Widen E, Ferrannini E (1993) Insulin resistance and insulin deficiency in the pathogenesis of Type 2 (noninsulin-dependent) diabetes mellitus: errors of metabolism or of methods? Diabetologia 36: 1326-1331

23. Pfeifer MA, Halter JB, Porte D Jr (1981) Insulin secretion in diabetes mellitus. Am J Med 70: 579-588

24. Seino Y, Kurahachi H, Goto Y, Taminato T, Ikeda M, Imura $\mathrm{H}$ (1975) Comparative insulinogenic effects of glucose, arginine and glucagon in the patients with diabetes mellitus, endocrine disorders and liver disease. Acta Diabetol Lat 12: 89-99
25. Yoneda H, Ikegami H, Yamamoto Y et al. (1992) Analysis of early-phase insulin responses in non obese subjects with mild glucose intolerance. Diabetes Care 15: 1517-1521

26. Kadowaki T, Miyake Y, Hagura R et al. (1984) Risk factors for worsening to diabetes in subjects with impaired glucose tolerance. Diabetologia 26: 44-49

27. Martinez SM, Tarres MC, Picena JC et al. (1993) eSS rat, an animal model for the study of spontaneous non-insulin-dependent diabetes. In: Shafrir E (eds) Lessons from animal diabetes IV. Smith-Gordon and Company Limited, London, pp 75-90

28. Makino S, Kunimoto K, Moraoka Y, Mizushima Y, Katagiri K, Tochino Y (1980) Breeding of a non-obese, diabetic strain of mice. Exp Anim 29: 1-13

29. Makino S, Yamashita H, Kunimoto K, Tsukahara K, Uchida K (1992) Breeding of the NON mouse and its genetic characteristics. In: Sakamoto N, Hotta N, Uchida K (eds) Current concepts of a new animal model: The NON mouse. Elsevier, Amsterdam London New York Tokyo, pp 3-10

30. King H, Rewers M et al. (1993) Global estimates for prevalence of diabetes mellitus and impaired glucose tolerance in adults. Diabetes Care 16: 157-177

31. Fujimoto WY, Leonetti DL, Bergstrom RW, Kinyoun JL, Stolov WC, Wahl PW (1991) Glucose tolerance and diabetic complications among Japanese-American women. Diabetes Res Clin Pract 13: 119-130

32. Dietrich WF, Katz H, Lincoln SE et al. (1992) A genetic map of the mouse suitable for typing intraspecific crosses. Genetics 131: 423-447 